\title{
ODWRÓT OD POLSKIEJ RACJI STANU
}

\author{
Każdy obiekt fizyczny, którego wptyw \\ oddziałuje ujemnie na środowisko, \\ popetnia samobójstwo.
}

Alfred N. Whitehead

Politykę zagraniczna rządu Prawa i Sprawiedliwości przedstawia się na różne sposoby, posługując się różnym kluczami czy metaforami. Rozważania, które się do niej odnosza, koncentrują się na podkreśleniu głębokości zmian na niektórych kluczowych jej kierunkach lub odwrotnie - na poszukiwaniu elementów ciagłości. Co do jednego panuje zgoda większości badaczy i komentatorów: polityka zagraniczna obozu rządzącego Polską od jesieni 2015 r. jest ściśle podporządkowana celom polityki wewnętrznej.

W zaproponowanym poniżej ujęciu pokazuję ją jako politykę odwrotu od polskiej racji stanu, rozumianej tak, jak została ona zdefiniowana przez obóz niepodległościowy po upadku komunizmu w 1989 r. Polityka zagraniczna Polski niepodległej i suwerennej została określona przez duet Tadeusz Mazowiecki - Krzysztof Skubiszewski, a stojąca za nią racja stanu została zdefiniowana w słynnym przemówieniu sejmowym ministra spraw zagranicznych z 21 stycznia 1993 r. Po nakreśleniu kontekstu pojęciowego i historycznego profesor Skubiszewski stwierdził:

W tej perspektywie racja stanu Polski nakazuje, aby w nadchodzących latach utwierdzać uzyskaną suwerenność, budować bezpieczeństwo państwa, wspierać gospodarczy i cywilizacyjny rozwój narodu i społeczeństwa oraz umacniać naszą pozycję na scenie międzynarodowej, zwłaszcza w Europie ${ }^{1}$.

Polityka zagraniczna wyrażała rację stanu nie tylko Polski niepodległej, ale też - nieodłącznie - demokratycznej i europejskiej. To były rzeczy ze soba ściśle powiązane. Obecny odwrót od racji stanu zaczyna się od zakwestionowania wizji Polski jako państwa demokratycznego leżącego w sercu Europy, tzn. państwa mocno identyfikującego się z projektem jedności europejskiej, zapoczątkowanym przez Wspólnoty Europejskie, którego kontynuatorem jest obecnie Unia Europejska. Trzeba w tym miejscu silnie zaznaczyć, że racja stanu i wywodzaca się z niej polityka zagraniczna rozwijana od 1989 r. dały

${ }^{1}$ K. Skubiszewski, Polityka zagraniczna i odzyskanie niepodległości. Przemówienia, oświadczenia, wywiady 1989-1993, Warszawa 1997, s. 301. 
Polsce ćwierćwiecze nadzwyczajnego rozwoju cywilizacyjnego i gospodarczego (najlepszego w porównaniu z innymi państwami byłego bloku sowieckiego $\mathrm{w}$ tym okresie) oraz dobra pozycję międzynarodowa, w tym zwłaszcza coraz mocniejszą pozycję w UE.

\section{OSEONA TENDENCJI AUTORYTARNYCH ZADANIEM POLITYKI ZAGRANICZNEJ}

Widocznym od początku celem polityki wewnętrznej obozu rządzącego jest zbudowanie państwa autorytarnego lub też według bardziej miękkich określeń - państwa nieliberalnej demokracji, demokracji dekoracyjnej. Celem czysto politycznym formuły ustrojowej, do której ustanowienia zmierzają rządy Prawa i Sprawiedliwości, jest zapewnienie sobie władzy bezterminowo. Chodzi o zminimalizowanie szans opozycji politycznej równoprawnego udziału w życiu politycznym i jej ewentualnego zwycięstwa w przyszłości. W sensie ustrojowym to jest próba połączenia doświadczeń takich państw, jak Białoruś, Meksyk rządzony kilkadziesiąt lat przez Partię Rewolucyjno-Instytucjonalna lub Wenezuela Chaveza. Tych porównań może być więcej. Obóz rządzący poczyniłby już większe postępy na drodze do tej formuły ustrojowej, gdyby nie „hamujący” fakt przynależności Polski do UE i Rady Europy.

Intencje rządzącego Prawa i Sprawiedliwości odsłonił w pełni atak na Trybunał Konstytucyjny pod pretekstem skorygowania nadużycia popełnionego przez poprzedni obóz rządzący PO-PSL, który przedwcześnie wybrał dwóch członków TK. Reakcją na pozakonstytucyjne działania obozu rządzącego z grudnia i listopada 2015 r. były orzeczenia samego Trybunału, który działał zgodnie z mandatem zakreślonym przez Konstytucję z 1997 r. Aby usunąć przeszkodę na drodze do całkowitej swobody rządzenia, bez ograniczeń wynikających z zapisanych w Konstytucji standardów demokratycznego państwa prawa ${ }^{2}$, rządząca większość postanowiła „zneutralizować” Trybunał, czyli pozbawić go funkcji, jaka są konstytucyjny pełni w takim ustroju (opartym na zasadzie trójpodziału i równoważenia się władz). Atak na Trybunał doprowadził nie tylko do kryzysu ustrojowego ${ }^{3}$, ale także wywołał reakcję organów międzynarodowych, które mają stosowną kompetencję z uwagi na przynależność Polski do UE i RE - Komisji Europejskiej oraz Komisji Weneckiej. Jednoznacznie negatywnie o próbie likwidacji ustrojowej funkcji Trybunału Konstytucyjnego wypowiadały się także polskie środowiska i autorytety prawnicze niezależnie od opcji światopoglądowych ${ }^{4}$.

${ }^{2}$ M. Safjan, Polityka a Trybunat Konstytucyjny. Konstytucja - ostatni środek obrony przed polityka, „Ruch Prawniczy, Ekonomiczny i Socjologiczny” 78, 2016, z. 1, s. 35-42.

${ }^{3}$ B. Chrabota, Zdewastowany TK to tylko poczatek walki o państwo, „Rzeczpospolita” z 23 grudnia $2015 \mathrm{r}$.

4 J. Stępień, To wyglada na zamach stanu, (rozmawiała A. Kublik), „Gazeta Wyborcza” z 20 listopada 2015 r.; A. Zoll, Za chwile będziemy żyli w państwie totalitarnym, (rozmawiała A. Kublik), „Gazeta Wyborcza” z 21-22 listopada 2015 r.; M. Safjan, Prezydent wkroczyt we władze Trybunatu, (rozmawiała E. Siedlecka), „Gazeta Wyborcza” z 23 listopada 2015 r. Wszyscy trzej byli w przeszłości prezesami TK. 
Zainteresowanie tych organów zagrożeniem dla zasad demokratycznego państwa prawa w Polsce spotkało się z wroga, antyeuropejską narracją obozu rządzącego. W poważnej części było ona wymierzona w opozycję polityczną i inne środowiska sprzeciwiające się naruszaniu Konstytucji; do najlżejszych oskarżeń skierowanych wobec opozycji można zaliczyć etykietowanie jej jako „Targowicy”, czyli narodowej zdrady. Sięganie po tego rodzaju epitety odsłaniało determinację rządzących sięgnięcia po „pełnię władzy” (bez konstytucyjnych ograniczeń), a zarazem miało na celu degradowanie opozycji w oczach opinii publicznej, zwłaszcza własnego elektoratu. Mogło to budzić obawy, że było to przygotowaniem uzasadnienia pod przyszłe represje wobec opozycji oraz ograniczenia praw i swobód obywatelskich ${ }^{5}$. Język obozu władzy ujawniał przy tym jego zgoła nieeuropejską mentalność i kulturę polityczną ${ }^{6}$.

Odwrót od demokracji i dążenie PiS do zbudowania państwa autokratycznego znajdowały potwierdzenie w błyskawicznym przejęciu przez tę partię mediów publicznych i uczynieniu z nich mediów partyjnych. Programy publicystyczno-informacyjne zaczęły przypominać język propagandy z czasów PRL. Dotyczyło to w szczególności podkreślania zasług i wyjątkowości ludzi władzy oraz dezawuowania i poniżania opozycji politycznej oraz środowisk opiniotwórczych przeciwnych metodom rządzenia PiS. Równolegle zostały przyjęte ustawy zwiększające uprawnienia instytucji i agend służących bezpieczeństwu publicznemu, aparatu represji (w tym środków inwigilacji obywateli oraz środków karnych, które mogą być teraz użyte wobec przeciwników politycznych obozu władzy). Administrację publiczną dotknęło zjawisko ,janczaryzacji”, czyli odejścia od kryteriów służby cywilnej na rzecz mianowania osób wprawdzie bez kwalifikacji i doświadczenia, ale tym bardziej za to wiernych wobec ośrodków dyspozycji politycznej. Masowo zwalniano osoby na stanowiskach powołane czy mianowane w administracji publicznej w poprzednich latach. Wymiana kadr w niektórych sektorach była głębsza niż w latach 19891990; przypominało to raczej okres przejmowania władzy przez komunistów zaraz po II wojnie światowej.

Wyraźne powinowactwo kierunku zmian ustrojowych przeprowadzanych w Polsce przez obóz Prawa i Sprawiedliwości do państw byłego Związku Sowieckiego było niekiedy tłumaczone formacją polityczno-światopogladową przywódcy tej partii Jarosława Kaczyńskiego. Idea nadrzędna jego koncepcji ustrojowej, czyli pełna suwerenność i niepodleganie żadnym ograniczeniom najwyższego ośrodka dyspozycji politycznej, pochodziła z nauk jego akademickiego mistrza i promotora (magisterium i doktoratu) prof. Stanisława Ehrlicha. Profesor Ehrlich w latach pięćdziesiątych XX w. specjalizował się w przenoszeniu na polski grunt sowieckiej doktryny państwa i prawa? Warto nadmienić, że „,ośrodek” rekomendowany przez S. Erlicha jest dzisiaj całkowicie pozakonstytucyjny, podobnie jak I sekretarz PZPR w PRL. Jarosław Kaczyński nie sprawuje żadnych funkcji państwowych; jest „zwykłym” posłem, choć

${ }^{5}$ R. Kuźniar, Czy grozi nam noc kryształowa, „Gazeta Wyborcza” z 12 kwietnia 2016 r.

${ }^{6}$ A. Wolff-Powęska, Jak gardza ludzie Kaczyńskiego, „Gazeta Wyborcza” z 16-17 stycznia 2016 r.

7 K. Mazur, Prezes i jego mistrz, „Rzeczpospolita” z 30-31 stycznia 2016 r. 
jednocześnie w jego partii nie ukrywa się, że to do niego należą najważniejsze decyzje realizowane przez obóz rządzący (rząd, większość sejmowa, prezydenta).

Koncepcję polityki obozu rządzącego można zamknąć w triadzie: autorytaryzm - nacjonalizm - populizm. Ideologicznym uzasadnieniem koncepcji silnego (autorytarnego) państwa jest naród, rozumiany przez tę formację polityczną jako wspólnota etniczno-religijna. Naród jest najwyższą wartością w programie PiS, a państwo głównym instrumentem realizacji jego interesów ${ }^{8}$. Naród jest portretowany jako stojacy ponad prawem suweren, którego woli wszyscy w państwie powinni być posłuszni. W praktyce suwerenem stała się partia, a przede wszystkim jej przywódca. Nie można wszakże poważnie posługiwać się argumentem woli suwerena w dążeniu do demontażu demokratycznego państwa prawa, gdy uzyskuje się poparcie w granicy 18,7 procent uprawnionych do głosowania (38,4 procent bioracych udział w wyborach). W programie wyborczym PiS nie było mowy o budowie państwa autorytarnego. Uprawniona jest zatem interpretacja, że narracja narodowa (nacjonalistyczna w praktyce, łączy się bowiem z licznymi wypowiedziami ksenofobicznymi, podskórnie antysemickimi) jest jedynie sztafażem ideologicznym, którego celem jest legitymizacja budowy „silnego państwa”. Inspiracje endeckie sa niezaprzeczalne, lecz wtórne wobec dążenia do zbudowania systemu władzy autorytarnej. Klasyczny w powojennych demokracjach w Europie przykład formacji politycznej stawiającej na swe sztandary „naród” - ruch gaullistowski - nie zawierał w sobie cienia skłonności autorytarnych.

W retoryce politycznej Prawa i Sprawiedliwości pierwiastek narodowy splata się silnie z pierwiastkiem klasowym. PiS szło do władzy pod hasłem walki z liberalizmem i nierównościami. Ćwierćwiecze wolnej Polski było przedstawiane jako czas, w którym dobrze się mieli (bogacili się) kapitaliści, bankierzy, reformatorzy-liberałowie, wolne zawody, wolne media (wszyscy oni powiązani, niekiedy służący „zagranicy”). Ofiara przemian w tej narracji był prosty człowiek, przeciętny Polak. Poprawa sytuacji w kraju, który był prezentowany jako państwo na granicy upadku, załamania, dysfunkcjonalności, ma zależeć również od ograniczenia swobody bogacenia się oraz od wsparcia dla biedniejszych. Rządzący wcześniej byli portretowani jako traktujący Polskę jako „ojczyznę dojną” (słowa prezydenta A. Dudy). Przywództwo PiS sięgało tu do egalitarystycznego sentymentu wyhodowanego w czasach PRL, skierowanego także przeciwko „niesłusznym” elitom. Populizm partii rządzącej wygrywał zarówno niższe instynkty sfrustrowanej części społeczeństwa, która nie czuła się beneficjentem polskiej transformacji, jak i wykorzystywał nierówności społeczne i dochodowe istniejące w każdym społeczeństwie, pojawiające się silniej w okresie tego rodzaju przemian i przyspieszenia rozwojowego, do którego doszło w Polsce po 1989 r. Rządowa propaganda oraz wykorzystywanie struktur śledczo-sądowych do wyszukiwania „afer” obciążających krytyków władzy czy symbolicznych kapitalistów-wyzyskiwaczy ma zaspokoić kreowaną przez PiS potrzebę „sprawiedliwości ludowej”. W tle wrogiem są różne odmiany liberalizmu. Przejawem tego populizmu jest także zarówno Program 500 plus

${ }^{8}$ Szerzej: Jaka zmiana? Założenia i perspektywy polityki zagranicznej rzadu PiS, Raport Fundacji Batorego z maja 2016 autorstwa A. Balcera, P. Burasa, G. Gromadzkiego, E. Smolara. 
(pomoc dla rodziców drugiego i kolejnych dzieci), który fałszywie odnosi się do prawdziwego problemu (regres demograficzny), jak i obniżenie wieku emerytalnego, choć w całej Europie - także z przyczyn demograficznych - robi się dokładnie odwrotnie. Populizm ma zapewnić bazę społeczną partii rządzącej, ale też stanowi wyraz rządowej niechęci do Europy portretowanej jako obszar kulturowego przerafinowania, wręcz dekadencji, a przy tym Europy, która wyzyskuje Polskę (Polaków) przy współudziale dotychczasowych elit z Polski (chociaż niekoniecznie prawdziwie „polskich”).

\section{PRZECIW INTEGRUJĄCEJ SIĘ EUROPIE}

Przemiany ustrojowe oraz klimat ideowy wnoszony przez obóz władzy tworzą tło dla jego polityki zagranicznej, a w niektórych przypadkach wręcz uzasadniaja podejmowane w jej ramach działania. Osobliwości polityczno-ustrojowe, które są jego dziełem i zamiarem (latem 2016 r. obóz rządzący był w tym zakresie nadal na początku drogi), wymagają całkowitej swobody od jakiejkolwiek presji powstrzymującej z zewnątrz. Piszą o tym trafnie autorzy cytowanego wcześniej raportu Fundacji Batorego: „dokonywanie niezbędnych zmian wewnętrznych ma być możliwe wskutek wyeliminowania możliwości ingerencji zewnętrznej”. I dalej: „Według PiS zmiany wewnętrzne w Polsce napotykają opór aktorów zewnętrznych, czyli - jak to określił prezes Kaczyński - establishmentu europejskiego (szczególnie Niemiec) oraz dużej części establishmentu amerykańskiego, które to siły albo już teraz przeciwstawiają się umocnieniu podmiotowości Polski w relacjach międzynarodowych, albo będa to robić w przyszłości" 9 . Punktem wyjścia takiego zachowania jest założenie o wasalnej roli Polski w poprzednich 25 latach. Takie stanowisko ignoruje całkowicie naturalne współcześnie procesy współzależności i integracji oraz współpracy państw także w sferze bezpieczeństwa. Wszystko to ma wpływ na praktykę suwerenności państw, zwłaszcza wysoko rozwiniętych. A przecież żadne z tych państw nie jest określane ani samo się nie określa jako wasalne lub o ograniczonej podmiotowości. Suwerennościowa narracja PiS i jej implikacje dla stosunków zewnętrznych są funkcją dążenia do zbudowania w Polsce ustroju autorytarnego bez „wtraccania” się uprawnionych instytucji międzynarodowych czy wyrażania niepokoju z tego powodu przez państwa zaprzyjaźnione i sojusznicze, głównych do tej pory partnerów Polski na scenie międzynarodowej.

Hasło o suwerenności ma być tarczą dla woluntaryzmu wewnętrznego. W taki sam sposób, jak zwykły posługiwać się nim Rosja, Chiny czy rządy państw afrykańskich krytykowane w ONZ za naruszanie praw człowieka, prześladowanie opozycji czy autokratyczny sposób rządzenia. Nic dziwnego, że po raz pierwszy w oficjalnej retoryce obozu rządzącego przywiązanie do suwerenności zostało zamanifestowane przez prezydenta Dudę właśnie w jego przemówieniu na forum ONZ w końcu września 2015 r. (jeszcze przed obję-

\footnotetext{
${ }^{9}$ Jaka zmiana? Zatożenia..., passim.
} 
ciem władzy przez rząd jego partii). Już w tym przemówieniu widoczny był silny anachronizm rozumienia prawa międzynarodowego $\mathrm{w}$ powiązaniu $\mathrm{z}$ postulatem suwerenności. Powtarzane tam przez prezydenta Dudę hasło „pokój przez prawo międzynarodowe” było przecież dewizą Ligi Narodów, która wiadomo, jak zakończyła swoje istnienie. Dzisiaj społeczność międzynarodowa jest daleko dalej w podejściu do pokoju i sposobów jego zabezpieczania: samo prawo nie wystarczy, konieczne okazują się zdolności do nacisku czy ingerencji wobec państw, które przez swe praktyki wewnętrzne zaczynają zagrażać bezpieczeństwu w ich otoczeniu. Owo selektywne, instrumentalne wobec potrzeb wewnętrznych posługiwanie się szyldem suwerenności polega również na ignorowaniu jednego z ważnych składników prawnomiędzynarodowej definicji suwerenności, zgodnie z którą „Każde państwo ma obowiązek w pełni stosować się w dobrej wierze do swych międzynarodowych zobowiązań..."10. Powyższy zapis znajduje potwierdzenie w Konstytucji RP z 1997 r., w art. 9, gdzie czytamy: „Rzeczpospolita przestrzega wiążącego ją prawa międzynarodowego”. Dość surrealistycznie na tym tle wyglądały okrzyki „,suweren”, „suwerenność” klubu parlamentarnego PiS, w tym premier Beaty Szydło, w czasie posiedzeń sejmowych, których przedmiotem było zainteresowanie Komisji Europejskiej (UE) oraz Komisji Weneckiej (RE) demontażem sądownictwa konstytucyjnego i innymi aktami wskazujacymi na odwrót od demokratycznego państwa prawa w Polsce. Wszak na to suweren nie dał zgody. W wyborach wyłoniony został rząd, który ma działać w ramach wyznaczonych przez Konstytucję. Obawy „Europy” zaś brały się stąd, że nieodległa historia zna przypadki, kiedy demokratycznie wybrane władze następnie dokonywały zamachu na demokrację (Hitler, Łukaszenka, Janukowycz).

Równie surrealistycznie wyglądało przyjmowanie przez obóz rządzący uchwały w sprawie suwerenności właśnie w kontekście sporu z Komisją Europejską ${ }^{11}$. Posłowie partii rządzącej okazywali zatrwożenie w obliczu rzekomego zagrożenia polskiej suwerenności ze strony... Unii Europejskiej (!). Polska okazała się w ten sposób jedynym państwem członkowskim, które takie lęki zamanifestowało. Nie próbowano w Sejmie bronić pozbawiania pozycji Trybunału Konstytucyjnego w systemie demokratycznego państwa prawa, gdyż to było niemożliwe, tylko wymachiwano sztandarem suwerenności, która stała się eufemizmem dla ustrojowego woluntaryzmu partii rządzącej. Wrażenie surrealizmu było tym większe, że część polityków tej partii nie ukrywa radości z kryzysu UE, a nawet zapowiada jej rychły upadek, więc taka Unia nie powinna stwarzać zagrożenia dla suwerenności państw członkowskich. Obecnie przecież bardziej prawdziwa jest sytuacja odwrotna: to państwa członkowskie zagrażają integralności unijnego projektu jednoczenia Europy (wcześniej

${ }^{10}$ Mówi o tym przyjęta przez ZO NZ 24 października 1970 r. Deklaracja zasad prawa międzynarodowego, w punkcie VI (Zasada suwerennej równości państwa), par. f.

11 Uchwała Sejmu w sprawie obrony suwerenności Rzeczypospolitej i praw jej obywateli została przyjęta głosami partii rządzącej 20 maja 2016 r. W uchwale odrzuca się właściwość UE w odniesieniu do kryzysu konstytucyjnego w Polsce i zapewnia, że prawa obywateli RP nie sa zagrożone. Jak wiadomo, gwarantem praw i wolności nie tylko w systemach demokratycznych nie są rządy czy partie rządzące, ale niezależne sądownictwo, w tym zwłaszcza sąd konstytucyjny, który może odrzucać ustawy zagrażające prawom człowieka. 
Grecja, teraz Wielka Brytania, a w kolejce ustawia się kilka innych państw, w tym Polska). Problemem nie jest zatem zagrożenie suwerenności Polski to problem sztuczny, wymyślony - lecz rewolucja ustrojowa, która wywołuje reakcje uprawnionych organów i mechanizmów międzynarodowych. Notabene wolna i suwerenna Polska z entuzjazmem uczestniczyła w ich tworzeniu, ich sens bowiem polega na zapobieganiu recydywie ustrojów niedemokratycznych w naszej części świata (reakcja na doświadczenie komunizmu).

Usunięcie flagi UE sprzed gabinetu premiera RP nie było przypadkowe. Trudno powiedzieć, czy także nieprzypadkowy był uśmiech na twarzy premier Szydło, gdy skierowanych przeciwko pozycji Trybunału Konstytucyjnego działań jej rządu w Parlamencie Europejskim bronili wrogowie Unii; być może polska premier nie rozumiała całej sytuacji. Niechęć obozu rządzącego do flagi unijnej - podobnie jak do całej UE - ma charakter czysto ideologiczny. Wszak zawarta na fladze symbolika nawiązuje do chrześcijaństwa czasów średniowiecza. Jest to jednak również niechęć programowa. Dotyczy Europy (Zachodniej), obecnej fazy jej cywilizacji oraz obecnego kształtu jej integracji, czyli UE. PiS wolałoby, aby UE nie było, aby jednoczenie Europy zatrzymało się na wczesnej fazie Europejskiej Wspólnoty Gospodarczej, czyli na wspólnym rynku. Mówił o tym wyraźnie minister Witold Waszczykowski w czasie swego sejmowego exposé - domagał się powrotu UE „do swoich korzeni”, czyli do „czterech wolności” ${ }^{12}$, co oznaczało nie tylko negowanie samej Unii, powstałej przecież w latach 1991-1992, lecz także rozwoju Wspólnoty od jej powstania w 1957 r. aż do końca lat osiemdziesiatych. Z obecnego kształtu integracji obóz rządzący akceptuje, nawet entuzjastycznie, fundusze unijne. One akurat się „Polsce należą”. Minister wypowiedział się także kategorycznie przeciwko dalszemu zacieśnianiu integracji oraz „ingerowaniu” Unii w wewnętrzne sprawy Polski.

Można bez ryzyka postawić tezę, że od chwili przejęcia władzy obóz rządzący kierowany przez Jarosława Kaczyńskiego prowadzi politykę de-europeizacji Polski. Oznacza to wprawdzie akceptację formalnego członkostwa Polski w UE, ale po pierwsze, wewnętrzne zmiany ustrojowe będą czynić Polskę w coraz mniejszym stopniu członkiem europejskiej wspólnoty wartości (wbrew temu, o czym zapewniał w Sejmie minister Waszczykowski). A po drugie, Polska PiS nie akceptuje obecnego modelu integracji, który przewiduje ponadnarodowe uprawnienia dla niektórych organów UE. Cała „pozytywna” wizja obozu rządzącego w sprawie UE zamyka się w haśle „Europy wolnych, suwerennych narodów (lub państw)”. Pojawiło się ono z całą mocą ponownie przy okazji Brexitu, który dla obozu rządzącego okazał się pretekstem do mówienia o potrzebie nowego traktatu, który miałby być odejściem „od Lizbony”, czyli początkiem dekonstrukcji $\mathrm{UE}^{13}$.

Trzeba z naciskiem stwierdzić, że to jest postulat całkowicie ahistoryczny. Taka Europa już była i w XX w. dwukrotnie kończyło się to wojnami światowymi. Kopernikański przewrót w historii Europy, w stosunkach pomiędzy

12 Informacja rządu o kierunkach polityki zagranicznej wygłoszona w Sejmie przez ministra spraw zagranicznych 29 stycznia $2016 \mathrm{r}$.

${ }^{13}$ Szerzej: O. Osica, Polska nie jest wyspa, „Tygodnik Powszechny” z 3 lipca 2016 r. 
jej narodami, polegał na uniemożliwieniu wojny poprzez bardzo szczególny projekt, jakim był plan Schumana i powołanie Wspólnoty Europejskiej. Cel przedsięwzięcia był od początku polityczny, a nie gospodarczy. Współzależność demokratycznych i wolnych narodów była i pozostaje kamieniem węgielnym tego projektu. Ograniczanie wolności narodów zaczynało się od budowy systemów autokratycznych wewnątrz państw, czemu Wspólnota (UE) ma zapobiegać. To jest proste i logiczne równanie. Znają je wszyscy w Europie. Owszem, warto kwestionować pojawiajacce się czasem uzurpacje UE w sprawach kulturowo-obyczajowych (PiS to także aktywnie robi), ale nie ma to nic wspólnego z demokratycznym rządami prawa, których demontaż jest istota problemu obecności Polski w UE od jesieni 2015 r. W obozie rządzącym pojawiły się aluzje, że jeśli Bruksela będzie kontynuować swoje zainteresowanie odchodzeniem w Polsce od demokratycznego państwa prawa, być może trzeba będzie rozważyć referendum w sprawie jej dalszego członkostwa w Unii (europoseł Z. Krasnodębski).

Stanowisko Polski w obu tych aspektach naszego członkostwa w UE - ustrojowym oraz instytucjonalnym - zaczyna skazywać nasz kraj na marginalizację we Wspólnocie. Skoro nie jest ona zainteresowana obecnością w „twardym rdzeniu" Unii oraz skoro ustrojowo będzie odbiegać od unijnego standardu, będzie tracić przyjaciół (to już się stało), a także będzie postrzegana jako członek drugiej kategorii. Obóz rządzący nie tylko chce pogorszenia stanu integracji, ale sam stawia Polskę na jej peryferiach. Polityka PiS „gorszej Polski w gorszej Europie" jest odwrotnością tego, czego wymaga polska racja stanu, odwrotnością tego, do czego Polska dążyła po odzyskaniu wolności i suwerenności, tzn. do „silnej Polski w silnej Europie”. Słaba, niespójna Unia straci swój atrybut solidarności, na czym Polsce zawsze zależało i z czego Polska korzystała. Nie będzie też wsparciem Polski w sferze bezpieczeństwa.

Egzemplifikacją stosunku Polski PiS do UE jest nowe podejście do Niemiec. Od początku zdystansowane i pełne podejrzliwości. Już wcześniej ten obóz dezawuował świetne stosunki Warszawy i Berlina oraz dobre osobiste kontakty premiera Tuska z kanclerz Merkel. Polska w narracji tego obozu była prezentowana jako wasal lub klient Niemiec albo też jako część „kondominium niemiecko-rosyjskiego". Niemcy podlegały ostrej krytyce ze względów historycznych oraz ze względu na ich pozycję w Unii, w tym dążenie do ściślejszej integracji. Od 2015 r. kanclerz Merkel oraz Niemcy były przez obóz PiS silnie krytykowane z powodu postawy, jaką zajęły wobec kryzysu uchodźczo-migracyjnego. W swoim exposé minister spraw zagranicznych wymienił je na odległym miejscu, po... Mołdawii. Obchody 25-lecia traktatu dwustronnego z 1991 r. przebiegły w chłodnej, choć poprawnej atmosferze. Obejmując władzę, obóz rządzący sformułował cztery warunki normalnych i partnerskich stosunków z Niemcami: dopuszczenie Polski do udziału w formacie normandzkim, rezygnacja Niemiec z Nordstream 2, modyfikacja pakietu klimatyczno-energetycznego UE oraz przyznanie statusu mniejszości Polakom zamieszkującym Niemcy. Były to właściwie „warunki zaporowe”. Istotnie, po kilku miesiącach złego klimatu w tych stosunkach rząd PiS uznał, że domagając się ich spełnienia, polityka polska na kierunku niemieckim znajdzie się $\mathrm{w}$ trwa- 
łym impasie. Z warunków zrezygnowano, jednakże antyniemiecka narracja, która została w tym kontekście rozwinięta, zrujnowała klimat zaufania, a przede wszystkim zdolność Warszawy do pozyskiwania Niemiec dla swych interesów. Niemcy nie sa łatwym partnerem, lecz dla Polski partnerem nieodzownym i niezastapionym. Rozmyślne psucie stosunków z nimi oraz odejście od koncepcji „polsko-niemieckiej wspólnoty interesów w jednoczącej się Europie" Krzysztofa Skubiszewskiego są złą przysługą oddaną polskiej racji stanu przez rządy PiS, które nie potrafią wyciagać wniosków z doświadczeń geopolityki i historii. To już ${ }^{14}$ jest szkodliwe, a może okazać się kosztowne. Wszak poza wszystkim złe stosunki polsko-niemieckie będą sprzyjać zbliżeniu Niemiec i Rosji. Obóz rządzący szybko unicestwił jeden z głównych atutów polskiej dyplomacji po 1989 r.

Zgasły również świetnie rozwijające się w ostatnich kilku latach stosunki z Francja. Ich elementem było m.in. sprawne porozumiewanie się prezydentów Komorowskiego i Hollande’a. Jedną z przyczyn ochłodzenia w relacjach Paryż-Warszawa było zatrzymanie rozmów finalizujacych zakup francuskich śmigłowców dla polskiego wojska. Głębszą przyczyną tego chłodu są jednak różnice ideowe, zwłaszcza w podejściu do Europy. Los stosunków z tymi dwoma, do niedawna kluczowymi, partnerami podzielił również Trójkąt Weimarski, także w poprzednich dekadach, niezależnie od wzlotów i upadków, pożyteczny instrument naszej dyplomacji.

\section{JEŚLI NIE EUROPA...}

W sytuacji, w której władze państwa kontestują jego miejsce w Europie oraz kontestuja dotychczasowy geopolityczno-instytucjonalny fundament polityki zagranicznej wolnej Polski, zasadne jest pytanie, na czym chca oprzeć nową politykę zagraniczna. Co ma być jej nowym fundamentem? Prezydent oraz rząd udzielają na to pytanie odpowiedzi: peryferie Europy i Unii Europejskiej. Co jest o tyle logiczne, że sami takie miejsce dla Polski wybierają.

W swoim sejmowym exposé szef dyplomacji wymienił Wielką Brytanię jako pierwszego partnera Polski w Unii. Przypomnijmy, to były już miesiace poprzedzające referendum w sprawie wyjścia lub pozostania Wielkiej Brytanii w UE. Czerwcowe referendum „zabrało” rządowi PiS głównego sojusznika we Wspólnocie. Obecna Warszawa sądziła, że wspólnie z Londynem będzie stanowić wewnątrzunijną opozycję wobec Unii. Pozostała sama. Wybór Anglii był tym bardziej niezrozumiały, że historycznie i geopolitycznie nigdy nie była ona solidarna z naszą częścią Europy. To przecież Londyn był autorem polityki appeasementu, czyli zaspokajania apetytu III Rzeszy kosztem sąsiadów z Europy Wschodniej. Pozostały Węgry Viktora Orbána, które były wcześniej

${ }^{14}$ K. Szczerski, Niemcy, nasz pierwszy partner, (rozmawiał J. Bielecki), „Rzeczpospolita” z 10 czerwca 2016 r. (minister ds. zagranicznych w Kancelarii Prezydenta uzasadniał wycofywanie się z czterech warunków wstępnych). P. Jendroszczyk, Polsko-niemiecka rocznica bez emocji, „Rzeczpospolita” z 16 czerwca 2016 r. 
inspiracją dla PiS (,będziemy mieli Budapeszt w Warszawie”). Orbán jest jednak o wiele bardziej pragmatyczny i sprytny. Jego wrogość wobec Unii nie ma charakteru ideologicznego. Nie zmierza tak otwarcie ku państwu autorytarnemu, nie eliminuje tak bezmyślnie ludzi kompetentnych z różnych sfer życia publicznego i gospodarczego. Wreszcie, ma sojusznika w postaci Putina. Świadomość, że najbliższym sojusznikiem prezesa Kaczyńskiego w UE jest najlepszy przyjaciel Putina w Unii, nie powinna dawać Polakom powodu ani do dumy, ani do spokoju.

Formacja rządząca Polską od jesieni 2015 r. szła do władzy z zamiarem budowy Międzymorza, silnego ugrupowania państw leżących między Bałtykiem, Morzem Czarnym a Adriatykiem. To hasło było mocno obecne w programie wyborczym Andrzeja Dudy. Na temat perspektyw stojacych rzekomo przed tym regionem rozwodził się minister Waszczykowski w sejmowym exposé. To pomysł nierealistyczny z wielu powodów; wiadomo o tym od stu lat. Od połowy $2016 \mathrm{r}$. przestał być jednak widoczny w polityce zagranicznej rządu PiS. Jego wcześniejsze pojawienie się świadczyło tyleż o iluzji, ile o ignorancji w tej sferze ${ }^{15}$. Na dłuższa metę Polski na to nie stać. No, ale jeśli nie silna Unia, to chimera silnego Międzymorza... Jeśli nie Trójkąt Weimarski z Niemcami i Francja, to Grupa Wyszehradzka z przyjaciółmi Putina - Orbánem i Zemanem. Owszem, nastapiła intensyfikacja spotkań w Grupy. Nowi polscy przywódcy wyraźnie lepiej czują się w tym towarzystwie niż w towarzystwie Merkel i Hollande’a. Jednak jedynym spoiwem Grupy okazał się sprzeciw wobec przyjmowania uchodźców z Bliskiego Wschodu, czyli program negatywny. Kierunek międzymorsko-wyszehradzki okazuje się słabą alternatywą dla UE i jej głównych mocarstw.

Endecka w pewnej mierze inspiracja dla obozu rządzącego mogłaby przynieść rezultat w postaci zbliżenia z Rosją. Sygnały, które wychodziły z tego obozu wcześniej, były mieszane. Sam szef dyplomacji w przemówieniu programowym w Sejmie mówił o nadziei na „pragmatyczne i rzeczowe stosunki z Federacją Rosyjską. Podobna pod względem sensu postawa poprzedniego rządu wywoływała oskarżenia ze strony PiS o uleganie Rosji. Można byłoby to krótko skwitować: chwalebna próba kontynuacji. Jeśli tak, to ze znacznie gorszym rezultatem, ponieważ obok nieprzyjaznej retoryki części obozu rządzącego, prawdziwych różnic i problemów, jest jeszcze polityka Putina, która uniemożliwia w tej chwili normalizację stosunków z Rosją. Poprzedni rząd i prezydent złymi stosunkami z Moskwą płacili przynajmniej cenę za wyjątkowe wsparcie dla Ukrainy w jej konflikcie z Rosja. Silny pierwiastek nacjonalistyczny obecny $\mathrm{w}$ ideologii PiS oraz takie nastroje w sporej części aktywu i elektoratu tej partii spowodowały osłabienie polskiej aktywności wobec Ukrainy, a bardziej stanowcze stawianie problemu ludobójstwa na Wołyniu będzie pogarszać ogólny klimat relacji dwustronnych Warszawa-Kijów, także na poziomie środowisk opiniotwórczych z obu stron. Ponadto słabością pozycji Polski wobec Europy Wschodniej stała się utrata jej roli jako przykładu demokratycznych przemian. Słaba pozycja w UE uniemożliwia wprzęganie Unii

15 Ł. Wójcik, Emocje i iluzje rzadza polska polityka zagraniczna, „Polityka” z 27 stycznia 2016 r. 
czy poszczególnych jej państw w naszą politykę wobec sąsiadów ze Wschodu, jak było to w przeszłości (tworzenie efektu synergii na tym kierunku). Zreszta zasadny jest pogląd, że przemiany ustrojowe forsowane przez obóz rządzący w Polsce są bardzo na rękę Putinowi, podobnie jak obecnie silnie eurosceptyczne i odśrodkowe pozycjonowanie się Warszawy w Unii ${ }^{16}$.

W czasie rządów koalicji pod przewodnictwem PiS w latach 2005-2007 rekompensatą za pogorszenie pozycji w Europie (sprzeciw wobec traktatu lizbońskiego, pogorszenie stosunków z Niemcami) miały być bliskie stosunki z USA. Również prezydent Lech Kaczyński wykazywał bezwarunkowo proamerykańskie sympatie. Tym razem ten sam schemat nie mógł się ziścić z uwagi na zamach na Trybunał Konstytucyjny. Jego odpowiednik w Stanach Zjednoczonych jest świętościa. Amerykańskie media i politycy wykazywali silny krytycyzm wobec antydemokratycznych poczynań nowych władz w Warszawie ${ }^{17}$. Dlatego, pomimo wielokrotnych prób podejmowanych przez stronę polska, nie doszło do wizyty dwustronnej prezydenta Dudy w USA ani do dłuższej rozmowy z prezydentem Obama ${ }^{18}$. Doszło do niej dopiero przy okazji szczytu NATO w Warszawie. W trakcie rozmowy (ok. $40 \mathrm{~min}$.) oraz po niej doszło do wyjątkowego dysonansu. Prezydent Stanów Zjednoczonych wyraził, także publicznie, swoje zaniepokojenie pogarszaniem się stanu demokracji w Polsce ${ }^{19}$. To zdarzenie bezprecedensowe. Nigdy po zakończeniu zimnej wojny główne mocarstwo Sojuszu Atlantyckiego ani jego sekretarz generalny nie wyrażali tego rodzaju obaw w stosunku do jednego z państw członkowskich. To naturalnie rzutuje negatywnie na pozycję Polski w NATO, zwłaszcza na pozyskiwanie przyjaciół dla polskich potrzeb i postulatów. Wprawdzie w czasie szczytu NATO w Warszawie podjęto decyzje o wzmocnieniu flanki wschodniej, czyli ulokowaniu także w Polsce jednego batalionu NATO, ale to była implementacja postanowień kierunkowych poprzedniego szczytu Sojuszu w Newport we wrześniu 2014 r. Sojusznicy chcieli w ten sposób zademonstrować jedność i stanowczość wobec Rosji. Jednak słabnąca pozycja Polski w NATO będzie jej utrudniać realizację jej interesów bezpieczeństwa w Sojuszu już w nieodległej przyszłości.

$$
* * *
$$

W nowej polityce zagranicznej Polski niepokojące jest jej spychanie w geopolityczne osamotnienie. Pozbawianie się sojuszników i przyjaciół na Zachodzie dokonuje się w sytuacji Putinowskiej ofensywy destabilizującej sytuację bezpieczeństwa w naszym bezpośrednim sąsiedztwie. Sytuację pogarsza fakt, że Rosja stara się z pewnymi sukcesami pozyskać sprzymierzeńców w różnych państwach Europy Zachodniej, zwłaszcza w środowiskach prawicowo-nacjo-

${ }_{16}$ W. Radziwinowicz, Moskiewskie nadzieje na Polske, „Gazeta Wyborcza” z 22 stycznia 2016 r.

${ }_{17}$ Poland Drifts in the Wrong Direction. Editorial, „International New York Times” z 7 lipca 2016 r.

${ }_{18}$ Prezydent Duda był dwukrotnie w USA (jesienią 2015 i wiosną 2016) i nawet za każdym razem chwilkę rozmawiał z prezydentem Obama, ale było to przy okazji konferencji międzynarodowych. Dla porównania: prezydent Komorowski został szybko zaproszony przez B. Obamę do Białego Domu (grudzień 2010), gdzie miała miejsca dwugodzinna rozmowa.

19 M. Zawadzki, Obama-Duda: pochwaty i niepokój, „Gazeta Wyborcza” z 9-10 lipca 2016 r. 
nalistycznych i antyeuropejskich, ale nie tylko. „Zrozumienie” dla znaczenia i potrzeb Rosji wykazuje poważna część kręgów rządzących w Niemczech, Francji czy we Włoszech; o Orbánie i Zemanie była już mowa. Świadczące o geopolitycznym irrealizmie sa w tym kontekście wypowiedzi czołowych polityków obozu rządzącego o „podnoszeniu się Polski z kolan”, o „odzyskiwaniu podmiotowości”, o prowadzeniu „polityki asertywnej” czy o „zapalaniu polskiej latarni”. Rzadkie połaczenie geopolitycznego analfabetyzmu, historycznej amnezji, sarmackiej tromtadracji oraz rażącej niekompetencji wskutek czystek kadrowych (na podobieństwo takich, jakie władza ludowa dokonywała w latach 1944-1947) już wyrządzają i będą wyrządzać coraz głębsze szkody polskiej racji stanu ${ }^{20}$. Pogłębiając niekorzystne tendencje $\mathrm{w}$ naszym bezpośrednim otoczeniu, które pogarsza się niepokojąco niezależnie od działań Polski, obóz rządzący zachowuje się tak, jak obiekt w cytowanej wyżej sentencji wybitnego filozofa nauki Alfreda N. Whiteheada.

prof. dr hab. Roman Kuźniar

Uniwersytet Warszawski

r.kuzniar@uw.edu.pl

\section{RETREAT FROM THE POLISH RAISON D'ÊTRE OR THE NATIONAL INTEREST}

\section{Summary}

The author of this paper proves the damaging effects of subjugating Poland's interests in external relations to a specific programme of domestic policy. The domestic policy of the Prawo i Sprawiedliwość (Law and Justice) government is to build an authoritarian state on the foundation of nationalism and populism. The conduct of this policy has led to an unavoidable conflict between Poland and its European neighbours. The European Union and the Council of Europe have obligations and the means to react in situations when democracy in the Member States is threatened. The effect of this conflict is the progressive marginalisation of Poland in the EU. The loss of the position within the EU cannot be compensated for by creating an Intermarium because this idea has been unrealistic since conception. The relationships between Poland and the US worsened when Obama's administration became sensitised to the setbacks in democracy in Poland, especially since they meant the virtual elimination of the political position of the Constitutional Tribunal. The ruling bloc does not have a positive vision either of relationships with Eastern Europe. All in all, we are witnessing a rapid deterioration in Poland's international position to the detriment of its ability to pursue its goals and its national interests.

${ }^{20}$ K. Szczerski, Zapalimy polska latarnię, (rozmawiał P. Wroński), „Gazeta Wyborcza” z 11 czerwca 2015 r.; R. Kuźniar, Dyplomacja po sarmacku, „Rzeczpospolita” z 15 kwietnia 2016 r. O „wstawaniu z kolan” mówił w odniesieniu do Chin Mao-tse-Tung, wtedy gdy jego polityka prowadziła tam do katastrofy gospodarczej i kulturowej. W polskich mediach elektronicznych popularny był na przełomie 2015 i 2016 mem-żart o Polsce, która „wstała z kolan i upadła na głowę". 